\title{
INSTITUTIONAL SUPPORT FOR ATTRACTING INVESTMENTS IN THE AGRARIAN SECTOR OF THE ECONOMY IN THE CONDITIONS OF INNOVATIVE DEVELOPMENT
}

\author{
Maksym Odnorog ${ }^{1}$, Nataliia Kraus ${ }^{2}$, Oleg Zagurskiy ${ }^{3}$
}

\begin{abstract}
Institutional dynamics refers to understudied processes both in economic theory and in economic practice. There is a lack of systematic knowledge on the composition, structure, and functioning of the basic socioeconomic institutions exactly of the investment process, therefore, the purpose of the paper lies in the study of institutional support for attracting investments in the agrarian sector of the economy. Methodology. The theoretical and methodological basis of research is the dialectical method of cognition and systematic approach through which there are theoretical and methodological foundations of strategic innovation institutes of the agricultural market. The results showed that the institutional environment of investment provision of the agrarian sector of the economy includes, on the one hand, agricultural producers with relevant on-farm structural units, managers, professionals, organizers of production and economic processes; in rural areas; local authorities and government; and on the other, a set of functionally competent institutions (legal, scientific, educational, informational, financial, controlling, deliberative, etc.). Each of these institutions has a corresponding purpose, socio-economic relevance, and is an integral part of this system. Practical implications. The studied institutions create incentives for the development of science and education, encourage the mobility of production factors, facilitate the transfer of scientific and technical information and the introduction of new technologies, promoting entrepreneurship and innovation. Conversely, inefficient institutions reduce the potential level of well-being, reduced reliability assurance of property rights and enforce contracts. Value/originality. The increasing importance of the institutional environment of investment provision of the agrarian sector of the economy gives an opportunity to define the latter as an important intangible factor in the development of agriculture and society as a whole, which creates the necessary conditions for transformation and development of the agrarian sector. The formation of a modern institutional environment should include a system of regulators, which would provide favourable conditions for attracting domestic and foreign investment, further structuring of the economic complex of the agrarian sector, the reduction of regional asymmetries of socio-economic development. How full the institutional environment of individual units of the investment will be depends on the realization of economic and social development priorities of the Ukrainian village.
\end{abstract}

Key words: institutional support, institutions, investing, investment, agrarian economy, agriculture.

JEL Classification: E11, G23, O17, G20, P33, E22, N50, 013, Q10, Q12, Q19

\section{Introduction}

With the rapid development of socio-economic relations in the country, an indispensable condition for increasing production efficiency, including in agriculture, is its institutional support, which mainly determines the performance of economic entities that operate in the economy. Therefore, the analysis of the status and the dynamics of institutional support becomes an integral part of economic systems management, including acquisition and management of investments. The acute need for such investments to guide them in the agrarian sector of Ukraine is caused

\footnotetext{
Corresponding author:

${ }^{1}$ State Educational-Scientific Establishment “Academy of Financial Management”, Ukraine.

ORCID: http://orcid.org/0000-0002-6650-6181

E-mail: odnorog_BTNAU@ukr.net

${ }^{2}$ Borys Grinchenko Kyiv University, Ukraine.

ORCID: http://orcid.org/0000-0001-8610-3980

E-mail: k2205n@ukr.net

${ }^{3}$ National University of Life and Environmental Sciences of Ukraine, Ukraine.

ORCID: http://orcid.org/0000-0002-5407-8466

E-mail: zagurskiy_oleg@ukr.net
} 
by the shortage of own financial resources. Investment policy and effective investment management are an important prerequisite, which can solve many problems in Ukraine. This issue becomes relevant due to the high importance of the institutional environment for the development of the provision of investment resources for agricultural producers.

Currently, in agricultural production, there is a tendency of reduction in volumes of financial resources. Most agricultural enterprises were faced with the problem of the accumulation of private capital for the implementation or modernization. The actual life of most fixed assets significantly exceeds the standard. The processes of reproduction and renewal of the material-technical base in the village almost stopped. Now in agriculture, there mainly operates a large number of investments that are little attractive, have outdated production capacity, able to produce highquality products in accordance with the requirements of international standards.

In market conditions, one of the main problems of the agricultural sector of Ukraine is to attract investment resources needed to modernise the sector and ensure on this basis production of competitive products. However, due to the significant number of unprofitable enterprises and low level of rate of profit of agricultural production compared to other sectors of the economy, the slow turnover of productive capital, due to the disproportion between production time and working period, insufficient protection of investor rights is low level of investments in the agrarian sector of the economy, which hinders the process of modernization and increase of production volumes of agricultural products. In these circumstances, the need arises to justify targeted public policy measures aimed at the intensification of investment processes in the industry, which will create conditions for the formation of food security of the state.

Attracting investment in the agricultural sector can be stimulated or constrained by the institutional environment that has formed, and a system of institutions, which develops in it.

Analysis of recent researches and publications shows that problems of the institutional environment are considered in the works of many well-known domestic and foreign scholars, namely, (Veblen, 1984), (North, 1997, 2000), (Shpykuliak, 2012), (Shebanin, Shebanina, 2011) and others.

However, a lot of questions on the institutional environment of investment support for agriculture, in particular, the influence of formal and informal institutional factors on the development of investment in the agricultural sector of the economy are studied.

Therefore, the scientific search and study of the mechanisms of changes to existing and the introduction of new formal and informal institutions of investment, developed over a long historical period, are ongoing challenges for science.
The goal of the article lies in the study of institutional support for attracting investments in the agrarian sector of the economy.

Theoretical and methodological basis of research is the dialectical method of cognition and systematic approach through which there are theoretical and methodological foundations of strategic innovation institutes of the agricultural market.

\section{Institutional component of agricultural policy in the agricultural sector}

Attracting investment is the most important factor of economic growth of any country and improving the welfare of the population. In the agricultural sector of Ukraine for the development of agricultural production, investment activity is a means of ensuring food security of the state, a guarantee of industry development and ecological environmental protection. Active measures at the state level should provide financial protection for agricultural production. At the heart of this must be the state financial protection and supporting agricultural producers with the use of various forms of state influence on the development of the agricultural sector.

In modern conditions, theoretical developments that allow taking into account changes in the institutional structure of the economy with the aim of increasing its effectiveness acquire a priority. The necessity of taking into account institutional factors is that they determine the level and additional opportunities to accelerate socio-economic development.

The institutional component is included into a number of the basic preconditions for the formation and development of investment policy in the agricultural sector of the economy.

And this is logical, because the applied nature of attracting investment is manifested through the interaction of very specific objects of the institutions, which are, on the one hand, agricultural producers agricultural enterprises, farms, private farms, agricultural firms, agricultural holdings, etc., and other state institutions, organizations, research and educational institutions, banks, financial and commercial structures, etc. The relationship between them in the process of implementing investment activities develops under the influence of economic, organizational, legal, and other factors in the macro environment, and directs the progress of activities carried out, occurs through the implementation of economic relations between stakeholders in the context of society's traditions, rules, norms, laws, mentality and worldview of the people.

In scientific literature, the term "institutional support" is interpreted in two aspects. On the one hand, as "institutions" - that take into account the customs, traditions, norms of behaviour, which are accepted in society, on the other hand as "institutions" - play laws, legal norms, social organizations, and the like. 
Institutes and institutions are phenomena that invariably accompany the development of economic systems. Their existence is a consequence of bounded rationality of man, which, a priori, has no opportunities and time for full, comprehensive analysis and justification of possible strategies. The emergence of institutes (institutions) is due to the attempt to save efforts on the acquisition and processing of information.

The terms "institute," "institution" come from the Latin words institutum (installation, implementation) and institutio, institutiones. In Latin, there is clearly discernible kind of semantic boundaries between these cognate concepts.

Further terms and institutum, institutio were perceived by many languages but researchers have begun to pay special attention to this notion only in the early nineteenth century. Justifying the essence of institutions, the scientists determined the scope of their competence in general and political institutions in particular. They focused on the fact that political institutions serve such a fundamental life needs, like security and social order. It is the goal of survival of the society in terms of its evolution gave rise, according to Herbert Spencer, the necessity of formation of the conciliation and coordinating a social subsystem features regulatory Institute, which was experiencing a political institution.

Contemporary works of Western authors clearly differentiated institution and institute and, although complete agreement on the definition of the essence of the "institute" and "institution" among them does not exist. Institutions are given the importance of symbolic, conventional, semiotic values and practices, strengthening and playback with the help of such social organizations as institutions (particularly political). D. North also clearly delineates the concept of institutions and organizations (institutions): "In this study, introduced a significant difference between institutions and organizations... Conceptually, what must be clearly differentiated are the rules from the players" (North, 2000).

Institutions according to D. North, are "the structures of the human brain" (North, 2000), "institutions are the rules of the game in a society or, more formally, are the humanly devised constraints that shape human interaction. In consequence they structure incentives in human exchange, whether political, social, or economic" (North, 2000), "range ban individuals something to do and the conditions under which they sometimes are permitted to engage in certain activities... consist of formal written rules as well, of course, unwritten codes of conduct that underlie and supplement formal rules" (North, 2000). D. North divides institutions into official (formal) and unofficial (informal). The first is legislation of a particular country; it enshrines the rules and regulations. Informal institutions are the customs, moral norms, and other unwritten rules of conduct.
A different situation is observed in post-Soviet countries. For example, in the sociological and economic traditions of Russia, there has established a kind of unity of these key concepts institutional analysis "institute" and "institution." Institutions are a phenomenon of both economic and non-economic order - the state, law, social organization and structure, customs, family and the like.

As the researchers note, was the actual loss of a specific category, which is "Institute." But in the studies on the institutional sphere, there is a semantic ambiguity of the concept of the institution as a norm and the Institute as an organization. The reason for the reduction of categorical apparatus of institutionalism in the Russian language researchers believe the consolidation of the term "Institute" (instead of "organization") in the process of erroneous translation of fundamental T. Veblen's Theory of the Leisure Class in its subtitle said it was about the institution (An Economic Study of Institution) and not institutions, as it was translated (Veblen, 1984).

The tradition of ignoring the term "institution" or its inadequate use during the translation from English or Russian language is also common in Ukraine. Although the title of the book of the founder of neo-institutionalism, D. North, which is printed in Ukrainian, it sounds clear: "Institutions, Institutional Change and Economic Performance" (North, 2000). Without knowing it, most of the domestic authors copy references to the Russian edition of this book entitled "Institutes, Institutional Change and Economic Performance."

The curvature of the methodological apparatus greatly simplifies the process of presenting results of such studies, because all phenomena are simply combined under a single notion of "institution" without a thorough theoretical analysis of their essence.

Clearly distinguishing between the concepts of institutions (rules of the game in society) and institutes, researchers in the latter are political bodies (state authorities and local self-government, political parties, etc.), economic bodies (firms, households, unions and the like), public, educational, religious organizations and the like.

According to V. S. Shebanin, institutional education is divided into production (the company), regulatory (enterprises, government, education), and regulatoryrestrictive (legal acts) (Shebanin, Shebanina, 2011).

The conviction O. G. Shpykuliak, economic institutes and institutions should be considered as formed by society and the state the relevant rules, norms, traditions, institutions; education, such as property, national economic mentality, as well as the legal structure, institutions, organizations - institutions that consolidate and direct human interaction in the economy (Shpykuliak, 2012).

Institutions are positioned as rules of the game or "regulators" and the market actors determine their level 
of adequacy of processes, which are subject to regulation. Economic Institute is an organization, institution, enterprise, the rule or standard of behaviour, operated and control system, the agreement and contract and the like. Based on well-known scientific tenets and practical life principles, it's safe to say that every type of socioeconomic system in its development managed by the relevant institutions (rules and norms) and institutions (structures that emulate them), including economic. For example, the market and the command economy functioned under the influence of the radically different institutional formations, especially in the formation of the motivational field of activity of economic agents. This belief shaped by history and nature of the consequences of institutional interactions. The model of the institutional system, forms and methods of management of the economy determines the behaviour of its participants, and thus forms the perspectives of effects on all levels of social life (Shpykuliak, 2012).

\section{Impact of the real economy on the institutional environment}

The real economy is developing not just under the influence of a particular set of institutions or through the functioning of particular institutions and within their specific structured set, which is determined by the specifics of the country. Institutions and institutions shape the institutional environment of the economy, which is characterized by a certain institutional structure. The latter links the various elements and subsystems, determines the nature of their interaction and thus lays the Foundation for the "solidarity" of functioning and development.

In the agricultural sector, there is the need to create an institutional structure that will provide exactly the competitive rules of the game, the regularity of transactions, the objectivity of economic laws, and the elimination of the dysfunctional market (Shebanin, Shebanina, 2011).

In economics, the institutional environment is considered as a set of fundamental political, social, legal, and economic rules that determine the scope of human behaviour and form the basis for production, exchange, and distribution. Thus, the institutional environment is clear, an ordered set of institutions that determine the framework conditions of functioning and development of economic entities (Shebanin, Shebanina, 2011).

The main precondition for the effectiveness of the institutional environment have effective institutions as the totality of political and socio-economic institutions determines the guarantee of fulfilment of contractual obligations by all economic agents and promotes the full utilisation of productivity of production factors underlying economic growth. These effective institutions ensure easy adaptability of the political-economic system to new conditions and opportunities that arise due to scientific and technical progress. Flexible institutions create incentives for the development of science and education, encourage the mobility of production factors, facilitate the transfer of scientific and technical information and the introduction of new technologies, promoting entrepreneurship and innovation. Conversely, inefficient institutions reduce the potential level of well-being, reduced reliability assurance of property rights and enforce contracts.

The necessity of activation of investment activity is that agrarian sphere of the economy of Ukraine is unable to develop without the involvement and effective use of investment.

Accumulating entrepreneurial, public, and mixed capital, providing access to modern technology and management, investments do not only contribute to the formation of national investment markets but also enliven the markets for goods and services.

Successful investment activity is possible under the condition of the creation of a favourable institutional environment, in which investment processes are forming the set of all macro- and micro factors that affect the decision of investors to invest. The aggravation of problems in the agrarian sector of the economy is largely due to the lack of investment support for modernization, reconstruction and technical re-equipment of agricultural enterprises, as well as the reproduction of their resource potential. This is due to the fact that it was too different and narrowed the range of sources of investment of large and small agricultural producers.

Improving the institutional environment of investment provision of the agrarian sector of the economy and diversifying sources of investments of agricultural enterprises require new methodological approaches in view of the increased European integration vector of development of our country and worsening of a range of economic and environmental problems of economic development of the resource potential of the agrarian sector of the economy.

Institutional analysis of investment activity in the agrarian sector of the economy involves the description of institutions and their interaction as a system and evaluates the system. By the main components of the institutional environment of investment provision of the agrarian sector of the economy (Figure 1), we can distinguish three main groups of institutions.

\section{The methodology of research of institutes}

The scientific literature recognizes the importance of institutions and the complexity of the methodology of their study. In the opinion of O. M. Moroz, identification of the presence, nature, and role of any institution should cover the subjective and objective description of the phenomena that are investigated. Each institution can be characterized by a spectrum of such features (Moroz, 2006): 


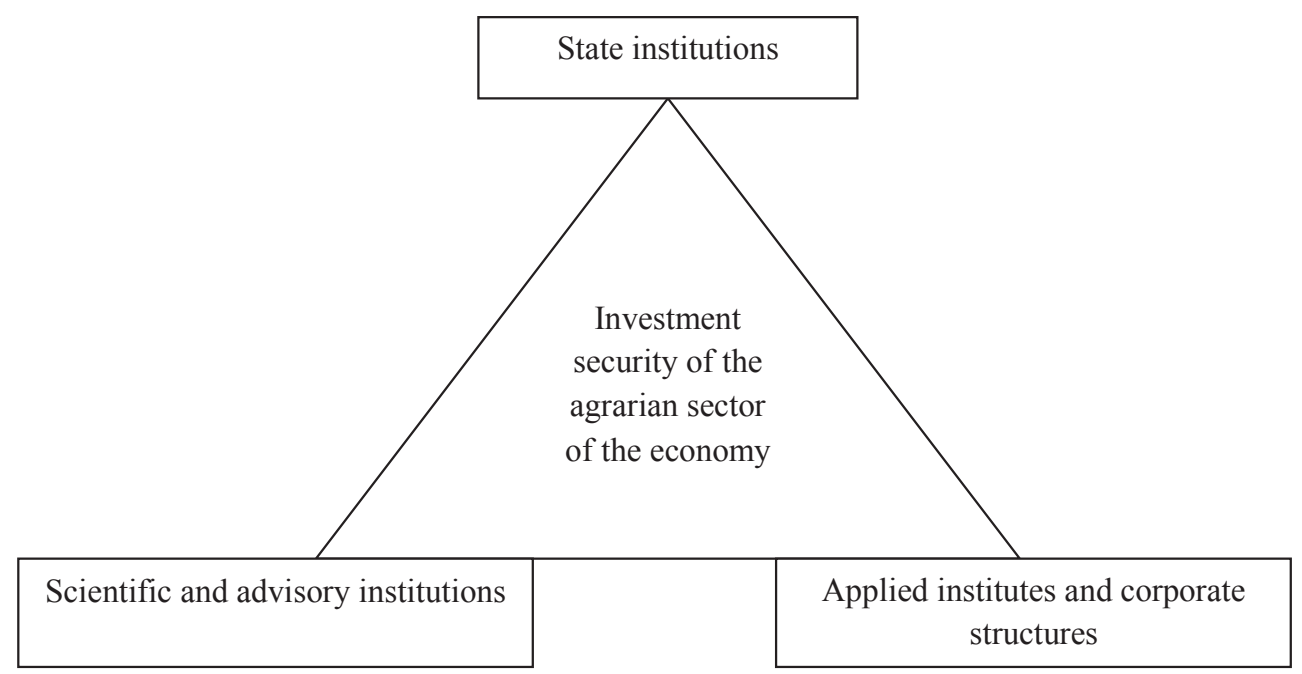

Figure 1. The main components of the institutional environment of investment provision of the agrarian sector of the economy

Source: developed by the author

1. The name of the Institute, the scope of activities of the facility, which deals with the institution, a general description of the nature of the Institute. 2. The essence of the basic norms of the Institute. 3. Real actors subject to the institutional norm. 4. The potential subjects, which may introduce an institutional norm. 5. The temporary identity of the Institute, the time and conditions of occurrence, validity period. 6. The degree of formalization of the Institute (formal or informal), consolidation and compliance with the legislative and regulatory base. 7 . The mechanism for monitoring compliance with the institutional norms; 8. The level of activity of the Institute (macro-, meso-, microlevel). 9. The level of regulativity, that is, how institutional norms are based on mechanisms regulation of such actions. 10. The level of constructiveness, that is, how these institutional norms contribute to the development, improvement, modernization. 11. The system of cooperation with other institutions. 12. The capacity of the Institute, availability of mechanisms for the support of the Institute (level of public perception and support). 13. The list of (simulation) of possible situations or phenomena that can be explained according to the Institute. 14. Mathematical or another device that can be used as tools of analysis. 15. Evaluation of expediency/efficiency of the institution (Moroz, 2006).

In more detail, the main institutions of the institutional environment of investment provision of the agrarian sector of the economy are represented in Figure 2.

\section{Findings}

The institutional environment of investment provision of the agrarian sector of the economy includes, on the one hand, agricultural producers with relevant on-farm structural units, managers, professionals, organizers of production and business processes; rural; local authorities and self-government; and on the other, a set of functionally competent institutions (legal, scientific, educational, informational, financial, controlling, deliberative, etc.). Each of these institutions has a corresponding purpose, socio-economic relevance, and is an integral part of this system.

\section{Conclusions}

Thus, the increasing importance of the institutional environment of investment provision of the agrarian sector of the economy gives an opportunity to define the latter as an important intangible factor in the development of agriculture and society as a whole, which creates the necessary conditions for transformation and development of the agrarian sector. The formation of a modern institutional environment should include a system of regulators, which would provide favourable conditions for attracting domestic and foreign investment, further structuring of the economic complex of the agrarian sector, the reduction of regional asymmetries of socio-economic development. How full the institutional environment of individual units of the investment will be depends on the realization of economic and social development priorities of the Ukrainian village.

Intensification of investment activity is not only the main condition for the withdrawal of the agricultural sector from the deep crisis but becomes the most important determining factor of its further development. It requires not only reforming the social order in the village by institutional changes that had priority in the initial period of agrarian reform, and 


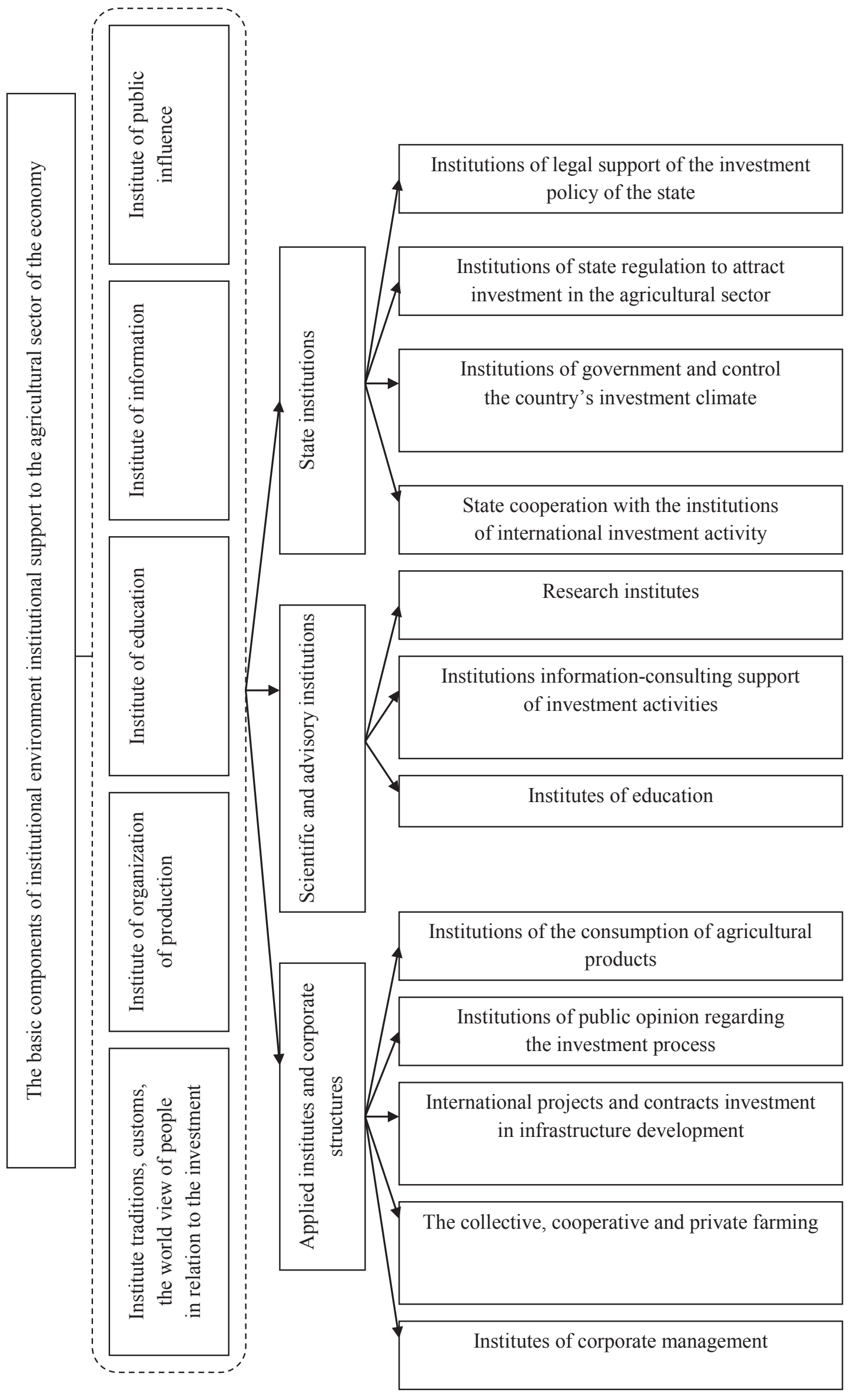


the involvement in the agricultural sector large-scale investment. Creating prerequisites for mass investment in the agricultural sector should be the most important element of the strategy of state agrarian policy at the present stage. First of all, it is necessary to provide at the state level creating a favourable, cost equivalent market environment, in which the economy becomes receptive to investment, and entities appear and expand investment opportunities for renewal of fixed capital and its increase at the expense of own and attracted means, including foreign capital.
In our country, much is now being done in order to significantly intensify the process of attracting investments, more needs to be done in the future; however, investors are well aware that the creation of an attractive investment climate with a stable, consistent, and transparent legal framework takes time. Many potential investors are ready to strengthen its presence and activities in Ukraine if the reform processes dynamically continue and it is seen that the state, represented by central and local executive authorities is promptly and purposefully working to address these deficiencies.

\section{References:}

Moroz, O. O. (2006). Instytucionalni osnovy rozvytku agrarnoi ekonomiky [The institutional framework for the development of the agrarian economy]. Avtoref. dys. ... d.e.n.: spec. 08.07.02.

North, D. (1997). Ynstytucyonalnyye yzmenenyja: ramka analyza [Institutional changes: framework of analysis]. Voprosy ekonomiky, 3, 6-17.

North, D. (2000). Instytucii, instytucijna zmina ta funkcionuvannja ekonomiky [Institutions, institutional change and economic performance]. Osnovy.

Shebanin, V. S., Shebanina, O. V. (2011). Znachennja instytucij v zabezpechenni efektyvnogo rozvytku APK [The importance of institutions in ensuring the effective development of the agroindustrial complex]. Visnyk agrarnoi nauky Prychornomorja, 3(60), 3-9.

Shpykuliak, O. G. (2012). Konceptualni aspekty pozycionuvannja rolovyh harakterystyk ekonomichnyh instytucij ta instytutiv v metodologii naukovogo dyskursu [Conceptual aspects of the positioning of the role performance of economic institutions and institutions in the methodology of scientific discourse]. Zbirnyk naukovyh prac VNAU, 1(56), 12-20.

Veblen, T. (1984). Teorija prazdnogo klassa [The theory of idle class]. Progress. 